DOI: https://doi.org/10.15407/techned2018.05 $: \underline{026}$

\title{
VOLTAGE HARMONIC DISTORTION IN AUTONOMOUS ELECTRIC POWER SYSTEM WITH AN ADJUSTABLE POWER LINE CONDITIONER
}

Journal

Publisher

ISSN

Issue

Pages
Tekhnichna elektrodynamika

Institute of Electrodynamics National Academy of Science of Ukraine 1607-7970 (print), 2218-1903 (online)

No 5, 2018 (September/October)

$26-30$

\section{Authors}
A.K. Zhuk ${ }^{*}$,
D.A. Zhuk ${ }^{\star *}$
D.V. Krivoruchko***

Admiral Makarov National university of shipbuilding,

Heroiv Ukrainy ave., 9, Mykolaiv, 54001, Ukraine,

e-mail: vicedirector2012@gmail.com

* ORCID ID : http://orcid.org/0000-0002-9069-475X

** ORCID ID : http://orcid.org/0000-0001-9782-1822

*** ORCID ID : http://orcid.org/0000-0002-8670-8872

\begin{abstract}
An improved analytical method for estimating of voltage harmonic distortions in autonomous electric power system with powerful semiconductor converter and adjustable hybrid power line conditionerhad been proposed. The adjustable hybrid power line conditioner consists from uncontrolled resonant filter and PWM regulated reactor compensator. The analysis of voltage piecewise related to steady state regime of the system, taking into account the mutual influence of its elements and their parameters had been fulfilled. Analytical expressions for the voltage
\end{abstract}


harmonic distortion factor, taking into account the entire voltage harmonics spectrum in a closed finite form, were obtained. The comparison of analytical calculations and computer simulation results had been executed. References 8, figures 3, tables 2 .

Key words: controlled filter-compensator gear, total harmonic distortion.

Received: 25.03.2018

Accepted: 13.04 .2018

Published: 16.08 .2018

\section{References}

1. Stohnii B.S., Kyrylenko O.V., Denysiuk S.P. Smart electrical grids of power systems and their technological support. Tekhnichna Elektrodynamika. 2010. No 6. Pp. 44-50. (Ukr)

2. Zharkin A.F., Novskiy D.O., Malakhatka D.O. Hybrid filter-compensating converters for the three-phase systems with nonlinear and variable loads. Tekhnichna Elektrodynamika. 2015. No 4. Pp. 48-52. (Ukr)

3. Mykhalskyi V.M., Sobolev V.M., Chopyk V.V., Shapoval I.A. The minimization strategy of undesirable instantane-ous power components with different topologies of shunt active filter. Te khnichna Elektrodynamika

. 2014. No 1. Pp. 41-50. (Ukr)

4. Zharkin A.F., Novskiy V.A., Palachov S.O. Regulatory and legal regulation of the quality of electrical energy. Analysis of Ukrainian and European legislative acts and normative and technical documents. Kyiv: Instytut elektrody-namiky NAN Ukrainy, 2010. 167 p. (Rus)

5. Zhuk A.K. Investigation of network filters influence on total harmonic distortion in autonomous electric power sys-tems with thyristor converters. Tekhnichna Elektrodynamika. Tematychnyi vypusk Sylova elektronika ta enerhoefek-tyvnist . 2004. Part. 2. Pp. 93-98. (Rus) 
6. Zhuk A.K., Zhuk D.A., Krivoruchko D.V. Controlled hybrid filter-compensating gear. Patent of Ukraine No 120790, 2017. (Ukr)

7. Atabekov G.Y. Fundamentals of circuit theory. Sankt-Peterburg: Lan, 2009. 432 p. (Rus)

8. Abramov B.Y., Parfenov B.M., Shevirev Ju.V. Methods for selecting the parameters of the step-type filter compen-sating devices for thyristor electric drives in systems of commensurate power. Elektrotekhnika. 2001. No 3. Pp. 38-42. (Rus)

$\underline{\text { PDF }}$ 